\title{
The Contribution of Intellectual Capital to Value Creation
}

\author{
Elena Shakina' ${ }^{1}$ Angel Barajas ${ }^{2}$
}

ABSTRACT This paper studies the marginal contribution of intellectual capital (IC) components to company
value using a hedonic pricing framework. The ANOVA is used to identify group differences among
different national markets and industries. Two models have been developed to reflect the time ef-
fect: one related to the immediate creation of value and another for the long term.

As could be expected, the contribution of IC to companies' value creation differs significantly between countries and industries. Both models, short- and long-term, are significant and with a normal explanatory power. We have found both positive and negative coefficients. Human capital plays a critical positive role in value creation in the short term. Structural and relational capital becomes more relevant in the long term. However, in the long term, the results obtained regarding the effect of human capital are unclear.

KEY WORDS: $\quad$ intellectual capital; hedonic price; contribution; value creation; EVA๑; FGV৫

JEL Classification: $\quad$ O12; L20; M21; J24

${ }^{1}$ National Research University Higher School of Economics, Russian Federation, ²Universidad de Vigo, Spain

\section{Introduction}

One of the most important issues for the strategic management of companies is the identification of value drivers. Several methods in the value-based management approach have been designed for this purpose. Most of these tools provide a factor analysis based on the assumption that only significant and manageable components should be considered as value drivers for a particular company. Taking for granted that a company is a portfolio of a number of interrelated resources, we expect that each of a company's capital components contributes to create value for investors. We could also suppose that this contribution should be

Correspondence concerning this article should be addressed to: Angel Barajas, Universidad de Vigo Fac. Ciencias Empresariales y Turismo Campus Universitario, Ourense, Ourense 32004 Spain. E-mail:abarajas@uvigo.es positive if we employ a particular resource efficiently and negative otherwise. Moving to the analysis of value creation, we are usually confronted by the concept of economic profit. Many researchers argue that intellectual capital is becoming practically the only competitive advantage for companies in the new economy (Bontis, 2003; Grant, 1991; Hysom, 2001; Wade \& Hulland, 2004); meanwhile, the concepts of economic profit and residual income are based on the fact that only the competitive advantages of a particular firm provide additional value creation. Therefore, the close connection between the modern concepts of valuebased management and intellectual capital becomes clear. We will thus assume that the key feature of intellectual capital is its ability to enhance the effectiveness of other resources, including tangible assets.

The idea behind this study is to investigate the contributions of different intellectual resources to company 
value. We use a hedonic pricing model to solve this problem. Because the hedonic pricing method is based on the fact that the prices of goods in a market are affected by their characteristics, we can draw an analogy that explains the enterprise value by the total value of all of the resources involved in company's activities. Moreover, because we consider only intellectual resources, we need to identify that part of the enterprise's value that is created by intangibles. The value-added indicators reflect the part of the value that is associated with the employment of intellectual capital. Thus, we suggest in this study that companies' added value is the quantity of all of their intellectual resources multiplied by their hedonic prices.

The database collected for this purpose consists of the financial and economic indicators underlying the evaluation of intellectual capital, such as strategic performance indicators - Economic Value Added $\left(\mathrm{EVA}^{\odot}\right)$ and Future Growth Value $\left(\mathrm{FGV}^{\odot}\right)$. We use panel data tools, such as "fixed effects", expressed in the steady quality of corporate governance. For this purpose, we will analyze a database of more than 400 European companies (2005-2009) from different industries: financial services, wholesale and retail trade, machinery and equipment manufacture, the chemical industry and, finally, transport and communications. Due to the nature of the database, which includes different countries and industries, it is appropriate to check if those differences affect the contribution of intellectual capital. Therefore, we will introduce this analysis in our study.

There are some methodological issues that we need to address. Firstly, we need to identify and measure the value of intellectual capital's inputs and outcomes. Then, we must specify the model by accounting for all the relevant factors that increase the value of the company. Finally, we need to address possible endogeneity - when stated in this manner, the problem of independent variables and determinants are mixed and there is some simultaneity as well as unobservable omitted variables.

As a result of this research, we expect to find a hedonic price for each component of intellectual capital, which will reveal the marginal contribution of the different intangibles. A cross-countries analysis provides a comparative study of intellectual capital's contribution to the future growth of value. Addition- ally, we will draw conclusions as to the robustness of the developed models.

This study provides information about the contribution of different intellectual resources to companies' present and future growth in value. It could also lend support to investment decision making.

The paper is organized as follows. The next section offers a brief overview of the literature, focusing primarily on the empirical analysis of intellectual capital's contribution to company value. In Section 3, we introduce the research design and describe the hedonic pricing framework applied by our study. Section 4 empirically tests the hypotheses proposed in our research. Section 5 presents the conclusions of the paper by briefly summarizing the main findings obtained. Finally, we note the limitations and implications of our study in the last section

\section{Theoretical background}

We apply a hedonic pricing approach to the analysis of intellectual capital's contribution to company value. This issue is obviously relevant from the investment point of view. Meanwhile, empirical studies tend to investigate the relationship between intellectual resources and company performance by considering only the significance and the sign of this relationship while ignoring the value of the contribution that those investments provide (see Bollen, Vergauwen \& Schnieders, 2005; Bontis, 2003; Cricelli, Grimaldi \& Hanandi, 2011; Le, Kroll \& Walters, 2012; Riahi-Belcaoui, 2003; Tan, Plowman \& Hanckock, 2007; Tovstiga \& Tulugurova, 2007; Tseng and Goo, 2005; Youndt, Subramaniam \& Snell, 2004). However, Giuliani (2013) analyses Intellectual Capital (IC) in terms of not only value creation but also the destruction of value due to intellectual liabilities.

Thus, conducting a critical analysis of the relevant empirical studies, which accomplish the aim of establishing the relationship between a company's intangibles and its value, we discover that the main restriction of the extant research is related to the interpretation of the estimates represented there. In the prospective investment analysis, the amount of the intangibles' contribution to company performance is of particular importance as the direction of spending and the application of management efforts must be supported and justified by a precise evaluation. In this regard, we find 

Lev (1999), Riahi-Belkaoui (2003), Stern (2001) consider $\mathrm{EVA}^{\oplus}$ to be one of the key proxy indicators for intellectual capital. They argue that economic profit is the welfare gain of a company through the effective use of resources. This reasoning underlies the assumption that a positive economic profit reveals intellectual capital. In that sense, recent VBM models such as EVA ${ }^{\odot}$ and Cash Value Added $\left(\mathrm{CVA}^{\circ}\right)$ could be considered to be proxy indicators of intellectual capital. Even when Mouritsen (1998) addresses EVA ${ }^{\odot}$ and IC, it could be said that the economic value added in a firm is a consequence of its IC. In that sense, $\mathrm{EVA}^{\circ}$ can be used as a proxy for Intellectual Capital despite the fact that, from a managerial point of view, they differ (Mouritsen, 1998). Moreover, an IC statement is "not a set of calculations that arrives at a digit for the worth of a firm's IC" (Mouritsen, 1998, p. 470). However, EVA ${ }^{\circ}$ provides a figure that can be used as proxy to conduct a quantitative analysis.

Another proxy indicator that is closely connected with economic profit is the value of future growth $\left(\mathrm{FGV}^{\odot}\right) . \mathrm{FGV}^{\odot}$ assesses the share of the market value attributed to EVA ${ }^{\odot}$ growth. In accordance with Stern Stewart \& Co., FGV ${ }^{\odot}$ "can be driven by market expectations of productivity improvements, organic growth and value-creating acquisitions." Meanwhile, $\mathrm{FGV}^{\odot}$ is the tool applied "in benchmarking against the "growth plan" of competitors and evaluating investors' assessment of the wealth creation potential of new strategies and opportunities" (http://www.sternstewart.com). Burgman and Roos (2004) show that a share of the future growth value of several companies grows every year and in some industries is characterized by the implementation of innovative products (this approach suggests that innovative behavior and an investment policy focused on the accumulation of intellectual capital provide a greater potential for future growth.

Let us draw an analogy between the identification of value drivers and those hedonic prices that have traditionally been applied to the analysis of tangible objects. In applying this tool to our research question, we seek to identify those characteristics of intellectual resources that have a significant influence on the proxy indicators of intellectual capital outcomes: $\mathrm{EVA}^{\odot}$ and $\mathrm{FGV}^{\odot}$. Meanwhile, as stated above, the $\mathrm{EVA}^{\odot}$ indicator reflects a short-term response in terms of value creation. $\mathrm{FGV}^{\odot}$ gives us a perspective picture of value growth taking into account investors' expectations.

The next section provides a short description of the research design based on the relevant theoretical and empirical studies.

\section{Research Design}

Because this paper explores the contribution of intellectual resources using a hedonic pricing approach, we specify the model as follows. In applying the hedonic pricing approach, we need to focus on value-based approach goal setting. Therefore, the research design of this study is closely connected to the relevant valuebased view models: economic value added $\left(\mathrm{EVA}^{\oplus}\right)$ and future growth value $\left(\mathrm{FGV}^{\odot}\right)$. This tool allows the discovery of the coefficients that reflect the marginal value of a particular component of intellectual capital.

We conduct the analysis in two steps:

- We look for the existence of significant differences between countries and industries using ANOVA. This analysis allows the confirmation or rejection of the hypothesis that factors of countries and industries affect the contribution of intellectual resources to company value.

- We conduct a panel data analysis designing a fixed effect regression. Applying this tool, we can avoid the endogeneity problem and gain consistent unbiased estimations. Meanwhile, this analysis has a number of shortcomings. It is impossible to estimate hedonic prices for those factors that do not slightly change over time. However, we obtain prices for some significant factors, and those estimates could be considered to be average unbiased hedonic prices reflecting the contribution of intellectual resources to company value.

Because we have an opportunity to compare companies from different countries and industries in our research, we should look to see if there are any significant differences between those markets. We propose the hypothesis that the external factors associated with the country or with one particular industry in which companies operate have an impact on their value drivers. The ANOVA provides a statistical test for whether the means of several groups are all equal. We use this tool in our research before estimating the hedonic prices of intellectual capital components.

In applying the hedonic pricing approach, we need to focus on the value-based approach of goal setting. 
This focus means that the research design of this study is closely connected with such relevant VBM models as economic value added $\left(\mathrm{EVA}^{\odot}\right)$ and future growth value $\left(\mathrm{FGV}^{\odot}\right)$. Intellectual capital is a heterogeneous resource. As such, we follow the approach suggested by Bontis and Fitz-enz (2002, p. 243), who maintain that "the intellectual capital literature states that there exist three primary components of intellectual capital: human capital (HC), structural capital (SC) and relational capital (RC)".

Therefore, our core econometric specification is

$$
\begin{aligned}
& E P=f(I C, C V)=f(H C, R C, S C, C V)= \\
& =\alpha_{0}+\alpha_{1} \cdot H C+\alpha_{2} \cdot R C+\alpha_{3} \cdot S C+\beta \cdot C V+\varepsilon
\end{aligned}
$$

$E P^{2}$ - economic profit indicators $\left(\mathrm{EVA}^{\odot}, \mathrm{FGV}^{\odot}\right)$;

$I C$ - intellectual capital components;

$C V$ - control variables;

$H C$ - human capital components of $I C$;

$R C$ - relational capital components of $I C$;

$S C$ - structural capital components of $I C$;

$\alpha_{i}$-hedonic price vectors;

$\beta$ - vector of coefficients by control variables.

If we need to estimate the equation on the basis of a panel data analysis, we should identify the nature of the fixed effect. We assume that the quality of corporate governance in a particular company is steady across time; this factor could not be observed and measured, but in applying the fixed effect tool, we solve the endogeneity problem. Accordingly, the specification for our model is

$$
E P_{i t}=\hat{\alpha}_{0}+\hat{\alpha}_{1} \cdot H C_{i t}+\hat{\alpha}_{2} \cdot R C_{i t}+\hat{\alpha}_{3} \cdot S C_{i t}+\hat{\beta} \cdot C V_{i t}+u_{i}+\varepsilon_{i t}
$$

$u_{i}$ - fixed effect expressed in the steady quality of corporate governance.

We have investigated firms from developed European countries, such as Finland, Denmark, Great Britain and Spain, and emerging markets including Portugal, Ukraine, Serbia and Turkey. The countries were selected according to their position in the KEI-based ranking Knowledge Economy Index (World Bank, 2009).

The datasets in this study were derived from a combination of several detailed longitudinal databases - Bu- reau Van Dijk (Amadeus and Ruslana) and Bloomberg. The database collected for the purposes of this study consists of the financial and economic indicators underlying the evaluation of intellectual capital - for example, the strategic performance indicators $\mathrm{EVA}^{\odot}$ and $\mathrm{FGV}^{\odot}$ as proxies of intellectual capital outcomes and a number of intellectual capital inputs' proxies.

It should be emphasized that most of the required data are specific and difficult to observe Thus, the database for this research includes figures from the annual statistical and financial reports as well as the different qualitative characteristics of the companies and industries analyzed. Table 1 presents the indicators list.

We have collected data from more than $400 \mathrm{com}$ panies. The final sample is a balanced panel for the period from 2005 to 2009 . We have used the following criteria to decide if a particular company should be included in the database:

- The number of employees should be no less than 500 and no more than 20,000 people.

- The firm should be publically traded.

The dataset compiled by the authors includes the following information:

- Common indicators - the company's age, industry, enterprise code and location

- Performance indicators - the economic value added and the future growth value

- Specific intellectual capital indicators (the proxies introduced in table 1)

To estimate this equation, we have used an entire range of proxy indicators, as presented in Table 1 . Most of the indicators mentioned were found in some of the theoretical and empirical studies that cover the issues being studied here, such as Barney (1991), Bontis (2003), Grant (1991), Rumelt (1991), Wade and Hulland (2004). Moreover, some of these proxies are presented in the practical application of the management of intellectual capital - the Sweiby Monitor or the Balanced Score Card designed by Norton and Kaplan. The procedure for estimating the value of each proxy was developed on the basis of the available information: patent bureau information, international rankings, company websites and search engines, amongst others.

In the next section, we briefly describe some of the empirical results that we collected in applying the research design of this study. 
Table 1. Comparative analysis of QMS document development models

Variable description

Dependent variables: intellectual capital outcomes

$\begin{array}{ll}\text { EVA }^{\odot} & \text { Economic value added } \\ \text { FGV }^{\odot} & \text { Future growth value }\end{array}$

Independent variables: intellectual capital inputs and factors of transformation

Common information

Age

Years in existence

Belonging to the industry (dummy)

Type of industry

Belonging to the country (dummy)

Location of the company's headquarters

Intellectual capital components: human capital

High efficiency of personnel (dummy)

Medium efficiency of personnel (dummy)

Board of directors qualification (categorical 0-2)
Proxy indicator of human capital quality: dummy variable. It is the difference between the earnings per employee and the costs of each employee divided by the number of employees. We have identified quartiles for the indicators'values and assigned 1 for the first quartile for a high level and 0 to the others. For the medium level, we have cut off any values that are less than the average of the sample.

Proxy indicator of human capital quality: dummy variable. It is the difference between the earnings per employee and the costs of each employee divided by the number of employees. For the medium level, we have cut off any values that are less than the average of the sample.

Proxy indicator of $\mathrm{HC}$ qualification. Criteria:

- If more than a third of directors have a postgraduate level qualification and more than 5 years experience: 2 points.

- If more than a third of directors have a postgraduate level of qualification or more than 5 years experience: 1 point.

- Any other: 0 .

Intellectual capital components: relational capital

Foreign capital employed (dummy) From the companies'Annual Reports, section "Common information". It has the value 1 if there is foreign capital and 0 otherwise.

Location within a city with over 1 From the companies'Annual Reports, section "Common information". It has the value 1 if million citizens (dummy) the headquarters is in a city with over 1 million inhabitants and 0 otherwise.

Presence of subsidiaries From the companies' Annual Reports, section "Subsidiary name". If a company has fewer than 100 subsidiaries, use the total number, otherwise use the following vector "First 100 out of $Y$ subsidiaries".

Well-known brand (dummy) Search for a company's name from the website: http://www.justmeans.com/top-global1000-companies If it has a rank, the value is 1, otherwise 0 .

Citations in search engines (categorical 0-7)
Search for a company's name and its score from the website: http://www.prchecker.info/ check_page_rank.php. Classified according to the score. 
Table 1. Continued

\begin{tabular}{|c|c|}
\hline Variable & Variable description \\
\hline $\begin{array}{l}\text { Integrate indicator of the site } \\
\text { quality (categorical 1-4)1 }\end{array}$ & $\begin{array}{l}\text { Search on a company's website and estimate the site quality according to the } \\
\text { following criteria: } \\
\text { - The availability of information for investors (special section or page) } \\
\text { - Multi-lingual information (with English language) } \\
\text { - } \quad \text { Amount of information (more than } 10 \text { pages) } \\
\text { - Design (using flash animation) } \\
\text { For every criterion, the company gains } 1 \text { point. The Integral Index is the sum of points. }\end{array}$ \\
\hline & Intellectual capital components: structural capital \\
\hline Intangible assets (th. Euros) & $\begin{array}{l}\text { From the companies' Annual Report, section "Financial data". The amount reported in } \\
\text { the balance sheet. }\end{array}$ \\
\hline Patents, licenses, trademarks & $\begin{array}{l}\text { Search for a company's name and the number of patents on the website QPAT: http:// } \\
\text { www.orbit.com. The number that appears there. }\end{array}$ \\
\hline $\begin{array}{l}\text { ERP, quality management systems } \\
\text { implementation (dummy) }\end{array}$ & $\begin{array}{l}\text { Search for a company's location on their website using such words as "ERP", "Oracle", } \\
\text { "NAVISION","NA", "SQL", "SAP" } \\
\text { If the company has information about these programs, assign 1, otherwise } 0 .\end{array}$ \\
\hline Owners/directors ratio & Company's Annual Report sections "Shareholder name" and "Directors information" \\
\hline
\end{tabular}

Note: ${ }^{1}$ - Each categorical variable was transformed into a dummy variable for the linear regression analysis.

\section{Empirical Results}

It should be emphasized that our data covers the period of the global financial and economic crisis of 2008-2009. As such, we obviously face the problem of companies' falling performance as well as a stagnating financial market. We need to consider this phenomenon when we draw our conclusions.

Table 2 (see Appendix) helps us to characterize the type of company and the period of time that were analyzed for our research. The table presents several descriptive features of the sample, and the mean and the standard deviation of the variables are detailed.

We do not have a strong partial correlation between the explanatory variables; therefore, we will not face a multicollinearity problem. Meanwhile, we observe a correlation between some independent and dependent variables according to the econometric specification of this research (see table 3 in Appendix).

The results of the analysis of the variance are presented in table 4. Mathematically speaking, because the P-value is less than $5 \%$, we cannot reject the null hypothesis that there are country differences in the sample of companies that we have analyzed. In other words, institutional and market factors significantly affect the contribution of intellectual capital to company value. We need to take this fact into account when estimating the hedonic prices of intellectual resources. In analyzing the sample of companies from different countries, we obtain an average estimation for the hedonic prices among different markets as well as the direction of price change according to a country's specific conditions. Those prices should be interpreted with a certain degree of caution. To investigate a particular national market, we should adjust the prices that we obtain in this study.

Moreover, we seek to analyze industry differences by supposing that those factors play a critical role in the transformation process of intellectual capital. This role, undoubtedly, has an impact on the marginal contribution of the components of intellectual capital. We have analyzed companies from industries with a predominance of varied intellectual capital components and, therefore, different configurations for intellectual capital. As such, we have selected the following industries: 
Table 4. Analysis of variance (country differences)

\begin{tabular}{lccccc}
\hline Source & SS & Df & MS & F & Prob $>$ F \\
\hline Between groups & $3.0932 \mathrm{e}+11$ & & $3.8665 \mathrm{e}+10$ & 2.31 & 0.0184 \\
Within groups & $2.2461 \mathrm{e}+13$ & 1343 & $1.6724 \mathrm{e}+10$ & \\
Total & $2.2770 \mathrm{e}+13$ & 1351 & $1.6854 \mathrm{e}+10$ & \\
\hline
\end{tabular}

Note: Bartlett's test for equal variances: chi2 $(8)=1.1$ e+03 Prob $>$ chi2 $=0.000$

Table 5. Analysis of variance (industry differences)

\begin{tabular}{lccccc}
\hline Source & SS & df & MS & F & Prob $>$ F \\
\hline Between groups & $1.9639 \mathrm{e}+12$ & 6 & $3.2732 \mathrm{e}+11$ & 21.16 & 0.0000 \\
Within groups & $2.0806 \mathrm{e}+13$ & 1345 & $1.5469 \mathrm{e}+10$ & \\
Total & $2.2770 \mathrm{e}+13$ & 1351 & $1.6854 \mathrm{e}+10$ & \\
\hline
\end{tabular}

Note: Bartlett's test for equal variances: chi2 $(6)=2.1$ e+03 Prob $>$ chi2 $=0.000$

financial services; wholesale and retail trade; machinery and equipment manufacture; chemical; transport and communications. We have chosen these particular industries because they represent a wide range of knowledge-intensive manufacturing and service sectors.

The ANOVA for different industries helps us to draw the conclusion that our proposition is correct (see table 5). We have examined country and industry factors for their significant differences for our sample. In hypothesizing that the companies represented in our sample are heterogeneous according to these criteria, we conducted the ANOVA analysis concerning the average return on IC in the country and industry subsamples (according to the $\mathrm{EVA}^{\odot}$ indicator). This analysis enables us to support our supposition that the above-mentioned factors play a pivotal role in the contribution of intellectual resources to company value. With the reference of these intermediate results, we included belonging to a particular industry and country in the core econometric specification control variables. However, these variables were subsequently transferred in the fixed effect of the model.
As mentioned earlier, interest in the study of intellectual capital has emerged due to its assumed ability to enhance the creation of value. Nevertheless, some empirical studies offer contradictory results that, on occasion, call into question the statements made in the papers. This problem is met, for example, in the papers of the following authors: Edvinsson and Malone (1997), Firer and Williams (2003), Yang (2008), Zeghal and Maaloul (2010).

According to the established approach to the theory of competitiveness and the concept of intellectual capital, the higher the degree of the efficiency for the intellectual capital, the more competitive and successful a company will be, as measured by $\mathrm{EVA}^{\odot}, \mathrm{FGV}^{\odot}$ and other measures. It is relevant to remark that hedonic prices can be negative or positive, reflecting the efficiency of the employment of intellectual capital.

We need to address the obvious issue of endogeneity. As stated, independent variables and determinants are mixed and there is some simultaneity and some unobservable omitted variables. Because we assume that the standard errors are correlated with the explanatory vari- 
Table 6. Fixed-effects (within) regression

\begin{tabular}{|c|c|c|}
\hline \multirow{2}{*}{ Dependent Variables } & Coef. & Coef. \\
\hline & Economic Value Added (EVA) & Future Growth Value (FGV) \\
\hline \multicolumn{3}{|l|}{ Independent Variables } \\
\hline Company age (c_age) & $-3060.27(-2.41)^{* *}$ & $102796.70(0.94)$ \\
\hline Belonging to the manufacturing industry & $-11494.25(-0.60)$ & $625955.30(0.45)$ \\
\hline Number of employees (ih_n_emp) & $.51(0.28)$ & $-255.63(-1.81)^{*}$ \\
\hline Board of directors' qualifications (ih_board_qf) & $3158.41(0.23)$ & $-1242675(-1.25)$ \\
\hline High efficiency of personnel (ih_emp_eff_h) & $63215.71(2.37)^{* *}$ & $-1.11 e+07(-5.53)^{* * *}$ \\
\hline Medium efficiency of personnel (ih_emp_eff_m) & $63700.77(7.78)^{* * *}$ & $444754.50(0.71)$ \\
\hline Well-known brand (ir_brand) & $-3378.94(-0.18)$ & $3708523(2.73)^{* * *}$ \\
\hline Citations in the search engine (ir_citatio d) & $21881.82(1.00)$ & $3349529(2.10)^{* *}$ \\
\hline Employment of foreign capital (ir_foreign l) & $-3846.05(-0.38)$ & $3734109(2.76)^{* * *}$ \\
\hline Location in a city with over 1 million citizens (ir_loc_pop) & $29701.77(1.35)$ & $2659953(1.61)^{*}$ \\
\hline Owners/directors ratio (ir_owners_ s) & $-7377.20(-0.22)$ & $-1270266(-0.51)$ \\
\hline Site quality (ir_site_qu d) & $-13119.26(-0.69)$ & $-2111138(-1.48)$ \\
\hline Number of subsidiaries (ir_subs) & $-51.60(-0.58)$ & $-12392.65(-1.91)^{*}$ \\
\hline ERP systems implementation (is_erp) & $-12037.03(-1.07)$ & $-413164.20(-0.50)$ \\
\hline Number of patents (is_patents) & $-23.46(-0.29)$ & $1584.92(0.27)$ \\
\hline Corporate strategy implementation (is_strategy ) & $-3840.85(-0.17)$ & $486255(0.30)$ \\
\hline Intangible assets (is_int_ass s) & $-98.31(-10.18)^{* * *}$ & $8685.953(12.27)^{* * *}$ \\
\hline Intercept & $107122.5(2.20)^{* *}$ & $-6866829(-1.44)$ \\
\hline Number of observations (Groups) & $1246(279)$ & $948(219)$ \\
\hline R-squared within & 0.19 & 0.26 \\
\hline$F(14,958)$ & $13.15^{* * *}$ & $14.61^{* * *}$ \\
\hline $\operatorname{corr}\left(u_{-} \mathrm{i}, \mathrm{Xb}\right)$ & -0.69 & -0.49 \\
\hline
\end{tabular}

Notes: ${ }^{*}$ Significant at $p<0.1 .{ }^{* *}$ Significant at $p<0.05 .{ }^{* *}$ Significant at $p<0.001$. 
ables, we should be able to reduce the impact of these shocks on the estimated coefficients (hedonic prices). Fixed effect regression provides one way to solve this problem. We use panel data tools, such as "fixed effects", as expressed in the steady quality of corporate governance. Taking that steady quality for granted, we can assert that these estimates are consistent and unbiased. There is no statistically significant spatial correlation existing between the independent variables.

Finally, we developed two models in accordance with the concept of the transformation of intellectual resources into company value. We have used the indicator of the immediate creation of value - $\mathrm{EVA}^{\odot}$ - and long-term company growth is expressed in the $\mathrm{FGV}^{\odot}$ indicator. Applying that approach, we had an opportunity to compare the hedonic prices for the characteristics of companies' intellectual capital at different time horizons.

Both models are significant and have normal explanatory power. We have discovered a number of significant coefficients that are obviously interpreted in terms of key value drivers.

The negative coefficient before the variable "company age" is explained on the basis of the life-cycle theory: the more mature the company is, the lower the growth rate of its value. In this sense, the price of companies' market experience is negative.

Two important characteristics of human capital are associated with positive and almost equal hedonic prices: the high and medium efficiency of a company's personnel.

It should be noted that the hedonic price of intangible assets is negative in the short run. This negative value could be associated with the long payback period for investments in this type of asset. In terms of the value added, we conclude that increasing the cost of capital by intangible assets will not provide a sufficient return on investments to cover opportunity costs.

Turning to the long-term return on intellectual capital investments as expressed in future growth value, we have evidence for the following findings:

A well-known brand is connected with a statistically significant hedonic price and could, on average, contribute to a value of more than 3.7 million Euros.

The employment of foreign capital is very important in the continuing creation of value. This result could be easily explained by the growing importance of competition for resources on the global financial markets.
This fact enhances companies' motivation to increase the efficiency of their activities.

The number of subsidiaries contributes negatively and is not covered, even over the long-term. We suppose that this type of relational strategy is not relevant given the conditions of the new economy.

Many citations in search engines mean that a company is widely represented on the Internet. Moreover, the company is popular and can provide benefits when developing a network with clients, suppliers and partners. The hedonic price of this intellectual resource of relational capital - is very high.

Location in a megacity is an important value driver for future growth as well as for immediate returns as expressed in added value. A location in a city with more than 1 million citizens is positively linked with company performance because it provides access to deep markets and effective demand.

Investments in intangible assets could be covered in the long run. The positive hedonic price of this characteristic is evidence for this fact.

Meanwhile, we have discovered some significant relationships that are not so obvious at first sight. Firstly, the high efficiency of an employee is negatively associated with value creation. We suppose that, others things being equal, human capital is no longer a core competitive advantage for a company over the long-term. Paying attention to the other drivers, we believe that marketing is a factor that is becoming more important for both developed and emerging European markets.

This finding also applies to company networks (subsidiaries). The development of information and telecommunication technologies has led to the decreasing attractiveness of projects that are connected with the expansion and penetration of different regions and markets. These projects could be replaced by more efficient ways of conquering markets.

\section{Conclusions}

In this study, we have justified the idea that hedonic pricing can be applied to identify the contribution of intellectual capital to a company's value. Moreover, this approach allows the extension of the investment decision-making base because it provides a comparative analysis of different intellectual capital components.

As has been addressed in this paper, the primary requirement for the discovery of hedonic prices is the 
ability of the econometric tool to provide consistent and unbiased estimates. We have suggested an analysis of panel data, specifying a model with a fixed effect. As stated in this paper, if we consider a short panel, we suppose that the individual characteristic of a particular company is steady corporate governance.

In applying this tool, we gained a number of significant results. However, they should be interpreted with a certain dose of caution. The primary problem that we faced in the research is the fact that our data covered a crisis period. Meanwhile, both of the hypotheses that we proposed in the study were confirmed.

The first hypothesis is related to the assumption that hedonic prices differ according to the institutional and economic conditions of the markets in which a company operates. That hypothesis has been confirmed because we found a significant difference between the groups of countries and industries that we analyzed.

The second hypothesis is based on the premise that hedonic prices could be positive or negative. This ability explains the contribution of intellectual capital to companies' value. We have found both types of prices in our study, and we have tried to interpret those results.

Two econometric models are introduced in this paper. The first model explains short run value creation using the $\mathrm{EVA}^{\odot}$ base. In analyzing this model, a number of significant hedonic prices for the components of intellectual capital are revealed. The most important conclusion following from this estimation is that human capital plays a critical positive role; meanwhile investments in structural capital, namely in companies' intangible assets, are not covered over the short-term.

Turning to the longitudinal value creation model, the following findings should be emphasized considering the FGV indicator:

Structural capital becomes more relevant in the long run. Well-known brands, as well as intangible assets, make a substantial contribution to company value, as associated with a relatively large positive hedonic price. Meanwhile, a subsidiary network no longer provides a competitive advantage for the company.

The second important issue relating to value creation is relational capital, as expressed in a well-known brand and accessibility to foreign investments. However, we had unclear results in relation to human capital. The negative hedonic price for the efficiency of staff should be tested as to its robustness.
Therefore, despite the fact that we need to perform further research into the findings made at this stage, the validity of the hedonic pricing tool in application for the evaluation of intellectual capital is justified.

\section{Limitations and implications}

The key restriction of the study arises from the essence of the statistical analysis. The framework could only be applied for the analysis of a firm as a typical representative of the sample. In that sense, the framework is not applicable for the specific analysis of a company. Interpreting the findings of the study, we can identify the following:

Whether a particular intangible resource makes a statistically significant contribution to the companies'value.

If the contribution is positive or negative. In terms of the value creation process, the contribution is interpreted as the ability of a particular resource (IC component) to provide enough return to cover all of the investments associated with it.

Comparison of the IC components' contribution to value creation - identification of more and less efficient investments in intangibles

Identification of industry and country effects (unbiased estimation of the effect values)

There are two specific limitations to this research. First, the results are very sensitive to the proxies selected for the analysis. Nevertheless, this is a common problem in this type of study. Second, the sample is not representative. Therefore, the conclusions can be properly referred only to the companies included in the database.

In our study, we advocated for the idea of implementing the technique of hedonic prices to a value creation process. This particular application of this common approach might be valuable for further research attempts as it provides both a possible interpretation of established results and an econometric tool (panel data-fixed effect) that provides consistent hedonic price estimates.

From the practical point of view, the outcome of our study is associated with company strategic management in the frame of a value-based approach. We state that the suggested tool might be considered for use as investment decision support for policy makers. As the hedonic prices of companies' intangibles reflect the marginal contribution of the different IC components to companies' value, their estimation 
provides useful information about the return on each intellectual resource. Moreover, this tool is applicable to the comparative analysis of a potential return on different intangibles and the dynamic analysis of a particular IC component.

\section{References}

Barney, J. (1991). Firm Resources and Sustained Competitive Advantage. Journal of Management, 17 (1), 99-120.

Bollen, L., Vergauwen, P., \& Schnieders, S. (2005). Linking intellectual capital and intellectual property to company performance. Management Decision, 43 (9), 1161-1185.

Bontis, N. (2003). Intellectual capital disclosure in Canadian corporations. Journal of Human Resource Costing and Accounting, 7 (1-2), 9-20.

Bontis, N., \& Fitz-enz, J. (2002). Intellectual capital ROI: a causal map of human capital antecedents and consequents. Journal of Intellectual Capital, 3 (3), $223-247$.

Burgman, R., \& Roos, G. (2004). Measuring, Managing and Delivering Value Performance in the Public Sector. International Journal of Learning and Intellectual Capital, 1 (2), 132-149.

Chen, C. J., \& Huang, J. W. (2009). Strategic human resource practices and innovation performance - The mediating role of knowledge management capacity. Journal of Business Research, 62 (1), 104-114.

Chen, M. C., Cheng, S. J., \& Hwang, Y. (2005). An empirical investigation of the relationship between intellectual capital and firms' market value and financial performance. Journal of Intellectual Capital, 6 (2),159-176.

Cricelli, L., Grimaldi, M., \& Hanandi, M. (2011). The HAI Model to Assess the Intellectual Capital: An Empirical Study from Jordan. Paper presented at International Symposium on the Analytic Hierarchy Process (ISAPH), June, 15-18, 2011, Sorrento.

Díez, J. M., Ochoa, M. L., Prieto, M. B., \& Santidrián, A. (2010). Intellectual capital and value creation in Spanish firms. Journal of Intellectual Capital, 11 (3), 348-367.

Donaldson, T., \& Preston, L. E. (1995). The stakeholder theory of the modern corporation: Concepts, evidence, and implications. Academy of Management Review, 20 (1), 65-91.
Edvinsson, L., \& Malone, M. (1997). Intellectual Capital: Realising Your Company's True Value by Finding its Hidden Brainpower. New York, NY: Harper Collins.

Firer, S., \& Williams, S. M. (2003). Intellectual Capital and Traditional Measures of Corporate Performance. Journal of Intellectual Capital, 4 (3), 348-360.

Gillard, Q. (1981). The effect of environment amenities on house values: The example of a view lot. Professional Geographer, 33 (2), 216-220.

Giuliani, M. (2013). Not all sunshine and roses: discovering intellectual liabilities "in action". Journal of Intellectual Capital, 14 (1), 127-144.

Grant, R. M. (1991). The resource-Based Theory of Competitive Advantage: Implications for Strategy Formulation. California Management Review, 33 (3), 114-135.

Hysom, R. (2001). Adding value to enterprise modelling. Production Planning \& Control, 2 (2), 119-127.

Kristandl, G., \& Bontis, N. (2007). Constructing a definition for intangibles using the resource based view of the firm. Management Decision, 45 (9), 1510-1524.

Le, S., Kroll, M. \& Walters, B. (2012). Outside directors' experience, TMT firm-specific human capital, and firm performance in entrepreneurial IPO firms. Journal of Business Research, 66 (4), 533-539.

Lev, B. (1999). R\&D and Capital Markets. Journal of Applied Corporate Finance, 11 (4), 21-35.

Li, M. M., \& Brown, H. J. (1980). Micro-neighbourhood externalities and hedonic housing prices. Land Economics, 56 (2), 125-141.

Meek, G. K., \& Sidney, J. G. (1988). The Value added statement: An innovation for the U.S. companies. Accounting Horizons, 2 (2), 73-81.

Molodchik, M., Shakina, E., \& Bykova, A. (2012). Intellectual capital transformation evaluating model. Journal of Intellectual Capital, 13 (4), 444 - 461.

Mouritsen, J. (1998). Driving growth: Economic Value Added versus Intellectual Capital. Management Accounting Research, 9 (4), 461-482.

Öztürk, M. B. \& Demirgüneş, K. (1997). Determination of Effect of Intellectual Capital on Firm Value via Value Added Intellectual Coefficient Methodology: An Empirical Study on ISE-Listed Manufacturing Firms. ISE Review, 10 (37), 59-77. 
Pike, S., Roos, G., \& Marr, B. (2005). Strategic Management of Intangible Assets and Value Drivers in R\&D Organizations. R\&D Management, 35 (2), 111-124.

Rappaport, A. (1986). Creating Shareholder Value - The New Standard for Business Performance. New York, NY: The Free Press.

Reis, H. J., \& Santos Silva, J. M. C. (2006). Hedonic Price Indexes for New Passenger Cars in Portugal (1997-2003). Economic Modeling, 23 (6), 890-906.

Riahi-Belkaoui, A. (2003). Intellectual capital and firm performance of US multinational firms: A study of the resource-based and stakeholder views. Journal of Intellectual Capital, 4 (2), 215 - 226

Rosen, S. (1974). Hedonic prices and implicit markets: product differentiation in pure competition. Journal of Political Economy, 82 (1), 34-55.

Rumelt, R. P. (1991). How Much Does Industry Matter? Strategic Management Journal, 12 (3), 167-185.

Sirpal, R. (1994). Empirical modelling of the relative impacts of various sizes of shopping centers on the value of surrounding residential properties. Journal of Real Estate Research, 9 (4), 487-506.

Stern, J. M., Shiely, J. S., \& Ross, I. (2001). The EVA Challenge: Implementing Value-Added Change in an Organization. New York, NY: John Wiley and Sons.

Stewart, G. B. (1991). The quest for value. New York, NY: Harper and Collins.

Tan, H. P., Plowman, D., \& Hancock, P. (2007). Intellectual capital and financial returns of companies. Journal of Intellectual Capital, 8 (1), 76-95.

Tovstiga, G. \& Tulugurova, E. (2007). Intellectual Capital Practices and Performance in Russian Enterprises. Journal of Intellectual Capital, 8 (4), 695-707.

Tseng, C. Y. \& Goo, Y. J. J. (2005). Intellectual capital and corporate value in an emerging economy: empirical study of Taiwanese manufacturers. R\&D Management, 35, (2), 187-201.

Wade, M., \& Hulland, J. (2004). The Resource-Based View and information Systems Research: Review, Extension, and Suggestions for Future Research. MIS Quarterly, 28 (1), 107-142.

Walden, M. L. (1990). Magnet Schools and the Differential Impact of School Quality on Residential Property Values. Journal of Real Estate Research, 5 (2), 221-230.
Williams, D. R. (2012). Human and financial capital as determinants of biopharmaceutical IPO de-listings. Journal of Business Research, 66 (12), 2612-2618.

World Bank (2009). Knowledge Economy Index. Available at http://data.worldbank.org/data-cata$\log /$ KEI

Yang, J. (2008). Antecedents and consequences of knowledge management strategy: the case of Chinese high technology firms. Production Planning \& Control, 19 (1), 67-77.

Youndt, M. A., Subramaniam, M. \& Snell, S. A. (2004). Intellectual capital profiles: An examination of investments and returns. Journal of Management Studies, 41 (2), 335-362.

Zéghal, D. \& Maaloul, A. (2010). Analyzing value added as an indicator of intellectual capital and its consequences on company performance. Journal of Intellectual Capital, 11(1), 39-60.

Zheng, W., Yang, B. \& McLean, G. N. (2010). Linking organizational culture, structure, strategy, and organizational effectiveness: Mediating role of knowledge management. Journal of Business Research, 63(7), 763-771.

\section{Endnotes}

1 EVAC and FGV( $)$ are estimated as in Molodchik et al. (2012), using the data available in the companies' financial reports.

\section{Acknowledgements}

We thank the referees for their anonymous work to improve the quality of this paper. We also thank the researchers and assistants of the Empirical Corporate Finance Laboratory (NRU Higher School of Economics Perm Campus) for their work creating the database and their support.

This study comprises research findings from the «The Changing Role of Companies' Intangibles over the Crisis» carried out within The National Research University Higher School of Economics' Academic Fund Program in 2013, grant No 13-05-0021. 


\section{APPENDIX}

Table 2. Descriptive Statistics

\begin{tabular}{lcccc}
\hline & Mean & Std. Dev. & [95\% Conf. Interval] & \\
\hline EVA $^{\circ}$, th. euros & $3,063.33$ & $4,861.36$ & $-6,476.70$ & $12,603.35$ \\
FGV ${ }^{\circ}$, th. euros & $2,037,831.00$ & $286,814.00$ & $1,474,982.00$ & $2,600,680.00$ \\
Number of employees & 4,615 & 149 & 4,321 & 4,907 \\
Intangible assets, th. euros & 234.41 & 16.28 & 202.47 & 266.36 \\
\hline
\end{tabular}

Table 3. Correlation analysis

\begin{tabular}{|c|c|c|c|c|c|c|c|}
\hline & EVA๑ & FGV $\odot$ & $\begin{array}{l}\text { Company's } \\
\text { age }\end{array}$ & $\begin{array}{c}\text { Board of } \\
\text { directors' } \\
\text { qualifications }\end{array}$ & $\begin{array}{c}\text { High } \\
\text { employee } \\
\text { effectiveness }\end{array}$ & $\begin{array}{l}\text { Well-known } \\
\text { brand }\end{array}$ & $\begin{array}{l}\text { Citations in } \\
\text { the search } \\
\text { engine }\end{array}$ \\
\hline EVAC & 1.00 & & & & & & \\
\hline FGV@ & $0.17(0.0000)$ & 1.00 & & & & & \\
\hline Company's age & $-0.03(0.2446)$ & $-0.06(0.0458)$ & 1.00 & & & & \\
\hline $\begin{array}{l}\text { Board of directors' } \\
\text { qualifications }\end{array}$ & $0.07(0.0051)$ & $0.10(0.0016)$ & $0.13(0.0000)$ & 1.00 & & & \\
\hline $\begin{array}{l}\text { High employee } \\
\text { effectiveness }\end{array}$ & $0.29(0.0000)$ & $0.37(0.0000)$ & $-0.12(0.0000)$ & $0.045(0.0843)$ & 1.00 & & \\
\hline Well-known brand & $0.19(0.0000)$ & $0.11(0.0003)$ & $0.09(0.0003)$ & $0.07(0.0095)$ & $0.15(0.0000)$ & 1.00 & \\
\hline $\begin{array}{l}\text { Citations in the } \\
\text { search engine }\end{array}$ & $0.02(0.3842)$ & $0.05(0.1315)$ & $0.18(0.0000)$ & $0.21(0.0000)$ & $0.09(0.0005)$ & $0.16(0.0000)$ & 1.00 \\
\hline $\begin{array}{l}\text { Location in a city } \\
\text { with over } 1 \text { million } \\
\text { citizens }\end{array}$ & $-0.06(0.0382)$ & $0.03(0.2997)$ & $-0.00(0.9105)$ & $0.09(0.0003)$ & $0.16(0.0000)$ & $0.03(0.2112)$ & $0.03(0.2712)$ \\
\hline $\begin{array}{l}\text { Owners/directors } \\
\text { ratio }\end{array}$ & $0.05(0.0672)$ & $-0.05(0.0874)$ & $-0.04(0.1456)$ & $-0.02(0.6552)$ & $-0.01(0.7261)$ & $0.19(0.0000)$ & $0.03(0.2837)$ \\
\hline Site quality & $-0.07(0.0096)$ & $0.01(0.7333)$ & $0.09(0.0004)$ & $0.14(0.0000)$ & $0.07(0.0032)$ & $0.01(0.6025)$ & $0.39(0.0000)$ \\
\hline $\begin{array}{l}\text { ERP systems } \\
\text { implementation }\end{array}$ & $0.10(0.0002)$ & $-0.00(0.9036)$ & $0.13(0.0000)$ & $0.06(0.0239)$ & $-0.04(0.1124)$ & $0.20(0.0000)$ & $0.20(0.0000)$ \\
\hline Intangible assets & $0.31(0.0000)$ & $0.52(0.0000)$ & $0.02(0.5224)$ & $0.06(0.0312)$ & $0.12(0.0000)$ & $0.28(0.0000)$ & $0.17(0.0000)$ \\
\hline $\begin{array}{l}\text { Strategy } \\
\text { implementation }\end{array}$ & $-0.00(0.9514)$ & $-0.04(0.1897)$ & $0.06(0.0122)$ & $0.35(0.0000)$ & $0.05(0.0356)$ & $0.06(0.0255)$ & $0.27(0.0000)$ \\
\hline
\end{tabular}


Table 3. Continued

\begin{tabular}{|c|c|c|c|c|c|c|c|}
\hline & $\begin{array}{l}\text { Location in } \\
\text { a city with } \\
\text { more than } \\
1 \text { million } \\
\text { citizens }\end{array}$ & $\begin{array}{l}\text { Owners } \\
\text { /directors } \\
\text { ratio }\end{array}$ & Site quality & $\begin{array}{l}\text { ERP systems } \\
\text { implementa- } \\
\text { tion }\end{array}$ & $\begin{array}{l}\text { Intangible } \\
\text { assets }\end{array}$ & $\begin{array}{c}\text { Strategy } \\
\text { implementa- } \\
\text { tion }\end{array}$ & $\begin{array}{c}\text { Citations in } \\
\text { the search } \\
\text { engine }\end{array}$ \\
\hline $\begin{array}{l}\text { Location in a city } \\
\text { with over } 1 \text { million } \\
\text { citizens }\end{array}$ & 1.00 & & & & & & \\
\hline $\begin{array}{l}\text { Owners/directors } \\
\text { ratio }\end{array}$ & $0.06(0.0355)$ & 1.00 & & & & & \\
\hline Site quality & $0.08(0.0007)$ & $-0.18(0.0000)$ & 1.00 & & & & \\
\hline $\begin{array}{l}\text { ERP systems } \\
\text { implementation }\end{array}$ & $-0.02(0.4518)$ & $0.03(0.2653)$ & $0.14(0.0000)$ & 1.00 & & & \\
\hline Intangible assets & $-0.00(0.7877)$ & $0.06(0.0267)$ & $0.05(0.0393)$ & $0.21(0.0000)$ & 1.00 & & \\
\hline $\begin{array}{l}\text { Strategy } \\
\text { implementation }\end{array}$ & $0.03(0.3127)$ & $-0.23(0.0000)$ & $0.39(0.0000)$ & $0.13(0.0000)$ & $0.03(0.1920)$ & 1.00 & \\
\hline
\end{tabular}


